\title{
Some Insights in the Historical Prospective of Hierarchy of Effects Model: A Short Review
}

\author{
Fazal ur Rehman*, Farwida Javed, Tariq Nawaz, Ishfaq Ahmed, Shabir Hyder \\ COMSATS Institute of Information Technology, Attock Campus, Pakistan \\ *Fazal_marwatpk@yahoo.com
}

\begin{abstract}
The study emphasized on the role of hierarchy of effects model in advertisement and reviewed its historical background along with different phases. This study clarified the early development phase, modern development phase, some challenges and defenses, and digital phase of the model in detail. The study highlighted different steps of hierarchy of effects model and how it effectively influence customers mind in advertisement. The study mentioned the steps of awareness, interest, desire, action which is also known as AIDA model. The study anticipated that AIDA is the oldest acronym of marketing. It is best, will never change and can be applied to print, social, mobile, online and digital advertising.
\end{abstract}

Keywords: Hierarchy of effects model, AIDA model, DAGMAR model, Advertisement

\section{Introduction}

Advertising is the aggressive type of a business promotion to show the face of business in target market. The aim of business promotion is to make sure that the people of target market know the company products and like it (Glowa, 2002). Advertising is considered to be effective when it increases the market shares and promotes sale. Advertisers try to draw attention of customers, involve them in advertisement and create positive perceptions' on their mind. For the reasons, they use different strategies to effectively convey their messages to target audience. Like, researchers discussed the message strategy with its three categories: Cognitive message strategy is used for creating positive influence on customers mind, beliefs and knowledge. Affective message strategies invoke the feelings of customers and for the enhancement of products likeability. Similarly, Conative message strategy is used to elicit behavior of customers (Clow \& Baack, 2007). Hierarchy of effects model is used to minimize the psychological hesitation in customer's attitude toward advertisements. "Hierarchy of effects model is based on the assumption that people first learn something from advertising, then form feelings about the product in question, and finally take action (Bovee et al., 1995)". Hierarchy of effects model is used to measure the effectiveness of advertisement in a stepwise series. This process begins with the awareness of product and result with the actual purchase of a product. The concept of Hierarchy of effects model has been used in advertisement for more than a century. Academic researchers have discussed its different dimensions, with different names like AIDA model, sales funnel, purchase process etc. and different phases (Peterson \& Arthur, 1959). Therefore, the study is interested to highlight its historical background, challenges, defenses and role in digital media.

\section{Advertising and Hierarchy of Effects}

Advertising is the paid form of a business non personal communication to target market about its products and services (Alexander \& Ralph, 1965). In the old business environment, advertising was considered to be a source of increasing sales of a company, but today it is also considered as an important source of customer services and a weapon to win the battle of competition (Gharibi et al., 2012). Effective advertising strategies influence customers mind and avoid wasted expenditure (Vakratsas \& Ambler, 1999). To assess the effectiveness of advertisement, the academic researchers and advertisement practitioners are widely using the hierarchy of effects model (Barry\& Howard, 1990; Weilbacher, 2001). Hierarchy of effect is a marketing theory presumes the process of purchasing that customers go through a series of steps that take place with attention, interest, desire and then ends up in purchase decision (Grover \& Vriens, 2006). According to another researcher, customer responds to a business advertisement in an ordered way that is starting from cognition than effects and finally conation (Wijaya, 2012). Conventional advertising hierarchy model is based on cognitive information processing and presume that attention is required as a first step and works as an 
antecedent for further information processing that proceeds in a hierarchic order from attention to action (Jarmo et al., 2010). According to Barry (1987), hierarchy of effects model have three categories which are discussed by the researchers: cognitive responses (e.g., recall), affective responses (e.g., attitudes) and behavioral responses (e.g., purchase intention or clicking behavior). Hierarchy of effects model was developed to evaluate the instant effects of advertising campaign (Cavill, \& Bauman, 2004). The literature of marketing and advertising leads to the conclusion that hierarchy of effects is not a single model, but lot of hierarchy of effect models have been developed over time by the researchers. The historical development of hierarchy of effect model has gone through different phases; early development, modern development and challenge \& defense phase (Barry, 1987).

Early Development Phase: In 1898, Lewis introduced the hierarchy of effects for the first time along with three steps; attention, interest and desire. A theoretical frame work was developed by Strong (1925a), where he described how business had to attract attention, maintain interest and create desire (AID) in order to be a market leader. After sometime, Lewis added another step "purchase action" and AIDA model came into existence. This model is still one of the most referred to models in the advertising and personal selling literature (Barry, 1987). In February 1900, Fred Macey considered an advertisement in the following respect: "The advertisement must receive attention, having attention it must create interest, having the readers' interest it must create desire to buy; having created the desire to buy it should help decision. In 1911, Arthur Frederick Sheldon gave suggestions that AIDA model is missing one important step of buying process and added another step "Satisfaction", and then the original model became AIDAS (Barry, 1987). Shortly thereafter, Strong (1922) suggested in a book on the psychology of selling life insurance that Sheldon five steps hierarchy was faulty. Strong (1922) objected to the five step process and suggested that it was both unnecessary and a waste of time to lead a prospect through the five hierarchical stages. According to Strong the five mental states (AIDAS) was not the goal the seller should strive for, he believed that this formulation was likely responsible for many poor advertisements and sales presentation. According to Barry (1987), West Coast Life Insurance Company in 1920, modified the model by presenting a five step model for successful advertisement as attracting attention, creating desire, removing inhibitions, inspiring confidence and impelling to action; to be known as ADICA. Strong (1925) worked on purchase process and identified that human beings involved in a series of mental steps that are "Want, Solution, Purchase and satisfaction". Soon after this, Strong (1925) reshaped his work and suggested that the process should be "Want, Commodity, Trade Name, Purchase and Satisfaction or Dissatisfaction" but very soon he realized that the process should be pleasant and removed the word Dissatisfaction. Strong (1925) concluded that purchasing process starts with rising wants and end with purchase action. Strong realized that sellers using different theories to influence people so he finally developed a theory to explain the customers purchase process: "Attention, Interest, Desire, Action, and Satisfaction" but he omitted the last element from his theory and finally the model is known as AIDA model.

Strong (1938), again presented the work of Hawkins, a Sales Manager of General Motors, who proposed that there are three stages of attention and three stages of interest that a selling prospect had to be carried through before desire could be reached. The main purpose of Strong's later work was to synthesize the three theories of selling which he introduced during "1925b" (AIDAS, appeals-response, and the dynamic man theory).In 1940, Bedell criticized AIDA model and suggested that one important step conviction is missing and presented five selling stratagems in his text "How to write advertising that sells": Attention, Interest, Desire, Conviction, and Action. Albert Fery presented his basic idea in 1947, where he suggested that those who create advertising must understand the mental steps through which consumers pass as they first learn about and then demand the advertised merchandise (William (2001), and further suggested that a person who is planning and building the advertisement should consider that their task consists of the following steps; "Attracting attention to the advertisement", "Endowing it with qualities that will create the interest of prospective customers and induce them to read it", "Presenting the idea in such a way that, once read, it will create consumer acceptance, and better still, consumer demand for the merchandise". Soon after this, Darrell Lucas and Steuart Britt(1950), in their text Advertising Psychology and Research, cast the hierarchy of advertising effects into a formula: "There is a popular advertising formula that contains the steps: attention, interest, desire, conviction and action". According to Devoe (1956), these models are not differentiating attention to the products versus attention to the advertisement and referred two psychological sequences: "attention, interest, desire, conviction and action" and "attention, interest, desire, memory and action". 
Modern Development Phase: Lavidge and Steiner (1961) were the first to connect the human psychological aspects of cognition, affect and connotation to the hierarchy of effects and kept the base of modern development phase. This phase is called the modern development phase because the human psychology is connected to the hierarchy of effects model. Lavidge and Steiner (1961) gave suggestions that customers may not go automatically to the fourth step i.e. action, without considering other elements of purchase process. They may passes through a series of seven steps to that threshold of purchase: Unawareness, Awareness, Knowledge, Liking, Preference, Conviction, and Purchase but the unawareness is not a necessary step of the series. These steps are not equally important and consumers take several steps simultaneously. Lavidge and Steiner felt that it is also possible that some consumers may develop a negative attitude towards these steps. Therefore, some of the steps had to be removed and the model was modified to three steps; Cognition (awareness or learning), Affect (feeling, interest or desire) and Behavior or conation (action). Lavidge and Steiner (1961) model is also known as the hierarchy of effects model. According to Barry (1987) it was at this stage in the development of the hierarchy of effects work that the popular terms of "cognition", "affect" and "Conation" were first used in reference to the actual hierarchy of advertising responses. Cognition referred to mental or rational states, affect to feeling or emotional states, and conation to the striving or behavioral states. Lavidge and Steiner views to the hierarchy of effects are presenting in the following table:

Table 1: Response Hierarchy Table

\begin{tabular}{lll}
\hline AIDA Components & Lavidge and Steiner (1961) & Behavioral \\
\hline Attention & Awareness and Knowledge & Cognition \\
Interest and Desire & Liking and Preference & Affect \\
Action & Conviction and Purchase & Connotation \\
\hline
\end{tabular}

Source: Adopted from (Belch \& Belch, 2009,]

At the same time, Coney's (1961) developed his model "awareness, comprehension, conviction and action hierarchy" in his famous book also known as DAGMAR - Defining Advertising Goals for Measured Advertising Results which was published by "The Association of National Advertisers". Coney's identified some other marketing factors which are associated with final sale are: competitively excellent product, availability of product to consumers, its attractive package design, proper functionality, support of personal selling, efficient promotion, publicity, competitive pricing strategies and so on. The main purpose of DAGMAR is the measurement of advertising campaigns. The DAGMAR advertising model has three parts: "define the advertising goals", "four steps: awareness, comprehension, conviction and action", and in the final part "to measure the advertising results". This is also used for improving the small business advertising campaign effectiveness (Dawn, 2012). The DAGMAR model also known as "Think-Feel-Do" model (Heuvel, 2012). The following figure is adopted for illustration (Heuvel, 2012).

Figure 1: Adaptation of the DAGMAR model

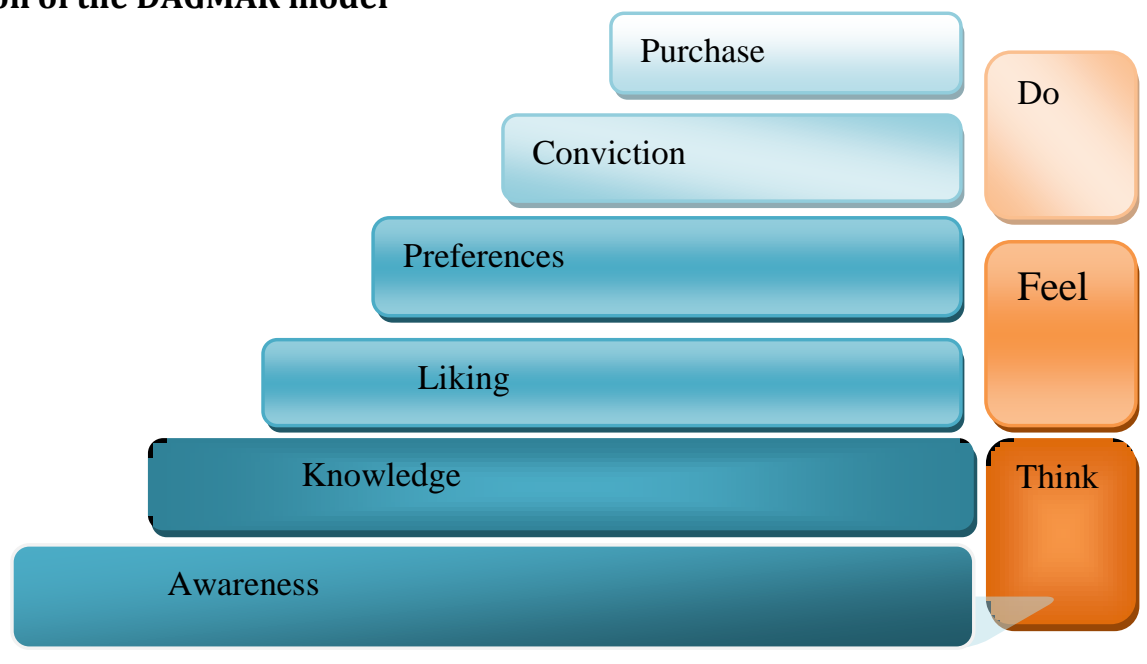




\section{Applying the Hierarchy of effects model}

\section{Stage Application}

Awareness: - $\quad$ To achieve awareness within your target market

Knowledge: - $\quad$ To test the knowledge about self and educating customers

Liking:- $\quad$ Customers begin to form opinions about your firm as they see you in ads

Preference: - Customers have a clear definition of why they want to do business with you

Conviction: - Customers have already been convinced that you are the right choice for their problems

Purchase: - Customers purchase without considering the Hierarchy of effects

The Think-Feel-Do model of message effects presumes that consumers think about something, when they form an opinion about it (means feel it), and then they take purchase action to try it (do). This model shows the three stages of effects called cognition (mental or rational), affection (emotional), and behavior (decision or action). The Think-Feel-Do model is the high- involvement model, because consumers are active thinkers. This model depicts a proper series of standard responses that normally found in consumers. This standard hierarchy is likely to be found where information's are needed. The second variation of the highinvolvement model is the Feel- Think- Do model, because consumers begin on the feeling stage where emotion leads to the purchase decision. In this stage customers are interested in products rather than personal significance. The third variation is the Think-Do-Feel model which changes the order of responses and also known as a Low - involvement model. In this model customers initially learn about a product, then try it, and finally form an opinion. In this situation customers initially take little interest in the product because there are little differences between products and required little decision making. The fourth variation which is called the "Do-Feel-Think" model where customer's initially tries something and learns from the practical experience. This model is called the rationalization model because customers select from several alternatives and make a decision by developing strong positive feelings about the product. This normally happens in low involvement sales items (Heuvel, 2012).

Table 2: Table Illustration of How Advertising and Marketing Communication Works

\begin{tabular}{|c|c|c|}
\hline & High Involvement & Low Involvement \\
\hline & Hierarchy of effects: Think $\rightarrow$ Feel $\rightarrow$ Do & Hierarchy of effects: Think $\rightarrow$ Do $\rightarrow$ Feel \\
\hline Rational & $\begin{array}{l}\text { Finding of expensive business purchases: } \\
\text { e.g. Car, Technological infrastructure. }\end{array}$ & $\begin{array}{l}\text { Buying of normally habit goods without } \\
\text { much thought: e.g. Lunch. }\end{array}$ \\
\hline & Hierarchy of effects: Feel $\rightarrow$ Think $\rightarrow$ Do & Hierarchy of effects: Feel $\rightarrow$ Do $\rightarrow$ Think \\
\hline Emotional & $\begin{array}{l}\text { Emotionally business purchases: e.g. } \\
\text { Fashion goods. }\end{array}$ & $\begin{array}{l}\text { Purchasing of goods where we don't spend a } \\
\text { lot of time on thinking: e.g. Movies, Birthday } \\
\text { cards. }\end{array}$ \\
\hline
\end{tabular}

Source: Adopted from (Heuvel, 2012)

Rogers (1962) introduced a model for a new product is known as response hierarchy model. Rogers also proposed that consumers go through a series of steps: awareness, interest, evaluation, trial and adoption. This adoption process model was further expanded by Robertson (1971) as awareness, comprehension, attitude, legitimating, trial and adoption. Several models and hierarchical proposition were presented during 1960 - 1970. Among these models there was a model of Aspinwall (1964) "the consumer acceptance hierarchy", where it is suggested that consumers first accept products, then prefer it, and finally insist on them. Sandage and Fryburger (1967) also presented their model which consists of a series of steps: exposure, perception, integration and action. William and McGuire (1969) presented their model as "An information processing model of advertising effectiveness" with a series of steps: Presentation, Attention, Comprehension, Legitimation, Trail and Adoption. Longman's and Kenneth (1971) also presented their model that is: informing customers and make exposures in their minds, then attending customers when they show their interest, educating customers and developing their minds, customers create deep beliefs about you, motivating towards you, and finally motivation and deep beliefs leads them toward action. Morris and 
Holbrook (1975) presented their views that customers mind setup is an important part of a hierarchy of effects model, customers perceive the message and submitting to their minds, and finally customers create attitude towards them.

Some Challenges and Defenses: Some other researchers presented their ideas that "Brand loyalty" is also an important part of decision making process of customers. Loyal customer's purchases your products because of their habits and trust in you, therefore, brand loyalty should be included to the sequence of hierarchy of effects model (Anderson et al., 1979). Richard and Vaughn (1980), challenged the traditional hierarchy of effects model that it is not necessary to follow the decision making process in the way "Cognition, Affects, Conation", and they gave their suggestion and added three additional models e.g. "Affect, Cognition, Conation" , "Conation, Cognition, Affect" , Conation, Affect, Cognition". Richard and Vaughn (1986) further suggested that there is not a single hierarchy in responding to message but there are multiple hierarchies which are used in the responding to messages of advertisement. Some other necessary factors like motivation and the ability to process the information in efficient way are the important parts of decision making process and for the immediate customer responses to advertisement (MacInnis \& Jaworski, 1989). At the same time, Petty and Caccioppo (1986) introduced the elaboration likelihood model (ELM). The ELM suggested the important variation in the persuasion and attitude change theories in the field of advertising. Persuasion process involves systematic thinking and cognitive shortcuts which are called "central route" and "peripheral route".

The central route normally show the persuasion process when elaboration is high, but is low in the case of peripheral route. The central route is normally used to evaluate the high involvement products while peripheral route for the evaluation of low involvement products. This model is concerned with the attitude which is formed under high elaboration then low elaboration. According to Petty and Caccioppo (1985) Elaboration Likelihood model consists of two elements: motivation, and ability. Similarly, Belch and Belch (2001) also recommended the elaboration model and its two elements i.e. motivation and ability. At the same time, Rossiter et al. (1998) presented their model: Category need, Brand awareness, Brand attitude, Brand purchase intention and purchase facilitation. They further suggested that marketers and advertisers should consider these steps because customers pass through these steps while going to purchase. The hierarchy of effects model is used in advertisement for more than 100 years because customers responds to a business advertisement in an ordered way usually cognition, effect and connation (Yoo et al., 2004). Consumer passes through a series of cognition, effect, connation when purchasing (Kotler, 2006). According to Smith, Chen and Yang (2008), with the passage of time marketers and researchers described the different stages, different steps and sequences of hierarchy of effects model but always has been a generalized form as a sequence of Cognition (attention), Affect (attitude) and in the end Conation (purchase). Ric Dragon (2011) gave valuable suggestions about AIDA model that "AIDA is probably the oldest acronym in marketing. It is the best and will never change".

Digital Phase of the Model: Use of AIDA model in advertising on digital media is not new. For example, Avon Products, Inc is a leading multinational personal care products company which has been in business since 1886. It is one of the oldest organizations that had used television for advertising. Avon have applied AIDA model for television advertisement campaigns. It has started TV advertising using AIDA model in 1953. While recently, a study by Mohammadi et al. (2012) applied AIDA model in studying the promotional mix for sports product companies. The study found that advertisement through TV has significant effects as compared to other advertising media like newspaper, radio, magazine etc. Moreover, study found that TV advertisement is more effective to create awareness and interest then all other media; however, face to face selling is more effective in purchase action then TV. The study also suggested marketing managers to avoid lake of planning about media in promotional mix and applying the concept of AIDA model. Wijaya (2012) suggested that AIDA model in digital and electronic media should be reformulated. Study suggested that some other elements like 'S' searching for interesting information, 'L' liking of products, 'S' sharing of pleasant experience and 'L' long term effects whether consumers love or hate are the important elements and the model should be treated as AISDALSLove. Ashcroft and Hoey (2001) emphasized the use of AIDA model in marketing segmentation on the internet. According to the study, usage of AIDA model in different market segments in the new media i.e. internet will be interesting for new studies. 
Ghirvu (2013) applied AIDA model to advergames for creating awareness and inducing interest by the use of promotional techniques like direct downloading from websites and informative commercial messages. According to the study, advergames give pleasure to consumer that lead to generate desire and positive influence, while sharing the game experience leads toward actual purchasing. Pradipta and Purwanto (2013) applied AIDA model in designing a website and its structure for affective attraction of customers and its role in purchase decision. It was suggested that all the elements of AIDA in term of website design have significant effects on purchase decision and one can apply the concept while designing a website. Baca et al., (2005), applied AIDA model for creating favorable attitudes in direct to consumers advertising. The study gave suggestions to examine younger population for building brand value. Wood and Burkhatler (2013), applied AIDA model in twitter marketing and found that it can be used in twitter and social networking sites for promotional purposes. It was suggested that twitter is effective marketing medium to draw attention, educate customers and encourage for seeking additional information's. The study also suggested that branded firms should use twitter for a wide pool of products to create awareness and influence opinions. Lukka and James (2014) applied AIDA model in Facebook advertising for determination of customers' attitude in social sites. The study found that by the use of AIDA model on the Facebook, customers' become aware of the products or services and would lead to purchase decision. However, study didn't found any evidence about the usefulness of banners in Facebook in creating action. The study also suggested that advertisers should avoid disruptive advertisements. Rehman et al., (2014) compared the email and mobile marketing using AIDA model. Results indicated that mobile marketing is more effective than email marketing while using the concept of AIDA model.

\section{Conclusion}

Businesses are investing a huge amount of money to promote their brands and stay connected with customers. Advertising is the source to keep update and inspire to purchase. For the assessment of advertising effectiveness hierarchy of effects model is widely used. Hierarchy of effects model is developed to evaluate the effects of advertising campaign on customers' mind. Literature discussed the hierarchy of effects model with different names, steps, phases. It is concluded that AIDA is the oldest marketing concept, which can be applied to print, social, mobile, online and digital advertising. The study has significant marketing implications by adding existing knowledge that the concept of AIDA model can be applied in digital marketing. The managerial approaching of the study was to assess whether AIDA model can be used in digital marketing. The study assumed that the concept of AIDA model can be used in traditional as well as digital marketing.

\section{References}

Alexander, T. \& Ralph, S. (1965). Marketing Definitions. Chicago, IL: American Marketing Association.

Anderson, R., Barry, L. \& Thomas, E. (1979). Advertising Management: Text and Cases. Columbus, OH: Merrill Publishing Company.

Aspinwall, L. V. (1964). Consumer Acceptance Theory. In Theory in Marketing, eds. Reavis. Cox, Wroe Alderson and Stanley J. Shapiro. Homewood, IL: Richard D. Irwin.

Ashcroft, L. \& Hoey, C. (2001). PR Marketing and the Internet: implications for information professionals. Library Management, 22(1/2), 68-74.

Baca, E. E., Holguin, J. J. \& Stratemeyer, A. W. (2005). Direct-to-consumer advertising and young consumers: building brand value. Journal of Consumer Marketing, 22, 379-387.

Barry, T. F. (1987). The development of the hierarchy of effects: An historical perspective. Current Issues and Research in Advertising, 10(1-2), 251-295.

Barry, T. E. \& Howard, D. J. (1990). A review and critique of the hierarchy of effects in Advertising. International Journal of Advertising, 9(2), 121-135.

Bedell, C. (1940). How to Write Advertising That Sells. New York: McGraw-Hill Book Company, Inc.

Belch, G. E. \& Belch, M. A. (2001). Advertising and Promotion. An Integrated Marketing and Communications Perspective. Fifth Edition. Boston: McGraw-Hill.

Belch, G. E. \& Belch, M. A. (2009). Advertising and Promotion: An Integrated Marketing Communications Perspective, 8th edn, The McGraw-Hill/Irwin, Boston.

Bovee, C., John, T., George, D. \& Marian, W. (1995). Advertising Excellence. New York: McGraw. Hill. 
Cavill, N. \& Bauman, A. (2004). Changing the way people think about health-enhancing physical activity: do mass media campaigns have a role? Journal of Sports Sciences, 22, 771-790.

Clow, K. E. \& Baack, D. (2007). Advertising design: Message Strategies and Executional Framework. Third Edition, Pearson Education.

Coney, R. H. (1961). Defining Advertising Goals for Measured Advertising Results. New York: Association of National Advertisers.

Dawn, B. (2012). What is The DAGMAR Advertising Model? Retrieved from: http://suite101.com/article/what-is-the-dagmar-advertising-model-a192307 accessed on Oct, 1, 2012.

Devoe, M. (1956). Effective Advertising Copy. New York: The Macmillan Company.

Dragon, R. (2011). Who Created AIDA? Retrieved from: http://www.dragonsearchmarketing.com/whocreated-aida/ . Accessed on 20-11-2013.

Gharibi, S., Danish, S. Y. S. \& Shahrodi, K. (2012). Explain the Effectiveness of Advertising Using the AIDA model. Interdisciplinary Journal of Contemporary Research Business, 4(2), 926-940.

Ghirvu, A. I. (2013). The AIDA Model for Advergams. The USV Annals of Economics and Public Administration, 1(17), 90-98.

Glowa, T. (2002). Advertising process models. White paper, North Country Research Inc.

Grover, R. \& Vriens, M. (2006). The Handbook of Marketing Research. Sage Publication Ltd. Thousand Oaks.

Heuvel, D. V. (2012). The Hierarchy of Effects. Retrieved from: www.marketingsavant.com/.../Hierarchy_of_Effects_BriefingPaper.p... accessed on, September 30, 2012.

Jarmo, K., Jaana, S., Liisa, U. \& Anssi, Ö. (2010). The Effects of Animation and Format on the Perception and Memory of Online Advertising. Journal of Interactive Marketing, 24, 269-282.

Kotler, P. (2006). Marketing Management. Pearson Education.

Lavidge, R. C. \& Steiner, L. (1961). A Model for Predictive Measurements of Advertising Effectiveness. Journal of Marketing, 25, 59-62.

Longman, K. A. (1971). Advertising. New York: Harcourt Brace. 255.

Lucas, D. B. \& Steuart, H. B. (1950). Advertising Psychology and Research. New York, NY: McGraw-Hill Book Company.

Lukka, V. \& James, P. T. J. (2014). Attitudes toward Facebook advertising. Journal of Management and Marketing Research, 14, 1-26.

Macey, F. (1900). The Bissell Prize Advertisement Contest, Hardware, p. 44.

MacInnis, D. J. \& Jaworski, K. (1989). Information Processing from Advertisements: Toward an Integrative Framework. Journal of Marketing, 53(4), 1-23.

McGuire, L. \& William, J. (1969). An Information-Processing Model of Advertising Effectiveness. Paper presented to Symposium on Behavioral and Management Science in Marketing. University of Chicago.

Morris, B. \& Holbrook (1975). A Review of Advertising Research. In John, A., Howard \& James, H., Advertising and the Public Interest, (eds), Appendix Two, Chicago: Crain.

Mohammadi, S., Esmaeily, N. \& Salehi, N. (2012). Prioritization of promotion tools based on AIDA model by Analytic Hierarchy process in production sector of sport industry. Archives of Applied Science Research, 4(4), 1670-1675.

Petty, R. E. (1980). The Role of Cognitive Responses in Attitude Change Processes. In Richard, E., Petty, Thomas, M., Ostrom \&Timothy .C. B. Hillsdale, NJ. Erlbaum: Cognitive Responses in Persuasion. Eds. 13-39.

Peterson, A. F. (1959). Pharmaceutical Selling. Heathcote-Woodbridge.

Pradipta, H. \& Purwanto, L. (2013). The Relationship of AIDA model in Term of Website Design and Structure towards Purchase Decision Zalora Indonesia (A Case Study of President University Student). G.J. C.M.P., 2(2), 1-13.

Rehman, F. U., Nawaz, T. \& Hyder, S. (2014). A Comparative Analysis of Mobile and Email Marketing Using AIDA model. Journal of Basic and Applied Scientific Research, 4(6), 38-49.

Rogers, E. M. (1962). Diffusion of innovation. New York: Free Press.

Robertson, K. \& Thomas, S. (1971). Innovative Behavior and Communication. New York: HoIt, Rinehart, Winston. 
Richard, T. \& Vaughn, K. (1980). How Advertising Works: A Planning Model. Journal of Advertising Research, 20, 27-33.

Rossiter, J. \& Percy, L. (1998). Advertising Communications \& Promotion Management Second Edition, Irwin McGraw-Hill, Singapore.

Sandage, C. S. \& Fryburger, V. F. (1967). Advertising Theory and Practice. ( $7^{\text {th }}$ edition), New York: McGrawHill.

Strong, P. \& Edward, K. (1922). The Psychology of Selling Life Insurance. New York: Harper \& Brothers Publishers,

Strong, P. (1925a). The Psychology of Selling and Advertising. New York: McCraw-Hill.

Strong, P. (1925b). Theories of Selling. Journal of Applied Psychology. 9, 75-86.

Strong, P. (1938). Psychological Aspect of Business. New York: McGraw-Hill Book Company, Inc.

Sheldon, O. \& Arthur, F. (1911). The Art of Selling. Chicago: The Sheldon School.

Smith, R. E., Chen. J. \& Yang, X. (2008). The Impact of Advertising Creativity on the Hierarchy of Effects. Journal of Advertising, 37(4), 47-61.

Tina, L. (2014). Analysis of "Avon" Ad-films using the AIDA Model. Retrieved from: http://marketingphilosopher101.blogspot.com/2012/08/analysis-of-avon-ad-films-using-aida.html. Accessed on 24-2-2014.

Vakratsas, D. \& Ambler, T. (1999). How advertising works: What do we really know? Journal of Marketing, 63(1), 26-43.

Weilbacher, W. M. (2001). Point of view: Does advertising cause a hierarchy of effects? Journal of Advertising Research, 41(6), 19-26.

Wijaya, B. S. (2012). The Development of Hierarchy of Effects Model in Advertising. International Research Journal of Business Studies, 01, 73 - 85.

William, M. W. (2001). Point of View: Does Advertising Cause a Hierarchy of Effects? Journal of Advertising Research, 41(6).

Wood, N. T. \& Burkhalter, J. (2013). Tweet this, not that: A comparison between brand promotions in micro blogging environments using celebrity and company-generated tweets. Journal of Marketing Communications, 20(1), 129-146.

Yoo, C. Y., Kim, K. \& Stout, P. A. (2004). Assessing the Effects of Animation in Online Banner Advertising: Hierarchy of Effects Model. Journal of interactive advertising, 4(2), 49-60. 